\title{
ELECTROCHEMICAL CHARACTERIZATION OF POLYLACTIC ACID-BLOCK-POLY (2- VINYLPYRIDINE)/GOLD NANOPARTICLE COMPOSITES FOR GLUCOSE BIOSENSOR DEVELOPMENT
}

\author{
Fathilah Ali, Jiajia Long and Wan Wardatul Amani Wan Salim \\ Department of Biotechnology Engineering, Faculty of Engineering, \\ International Islamic University Malaysia, Jalan Gombak, \\ 53100 Kuala Lumpur, Malaysia. \\ *Corresponding author: fathilah@iium.edu.my \\ (Received: ${ }^{\text {th }}$ Sept. 2017; Accepted: $17^{\text {th }}$ July 2017; Published on-line: $1^{\text {st }}$ Dec. 2017)
}

\begin{abstract}
Nanocomposites that consist of diblock copolymer (BCP) and gold nanoparticles (AuNPs) can be applied as a matrix to immobilize enzymes or other molecules, based on the well-defined core/shell nanostructures of these composites. In this research, polylactic acid-block-poly(2-vinylpyridine) (PLA-b-P2VP)/hydrogen tetrachloroaurate(III) hydrate $\left(\mathrm{HAuCl}_{4} \cdot 3 \mathrm{H}_{2} \mathrm{O}\right)$ composites were hybridized and then reduced in dichloromethane (DCM) solution. The hybridizations between gold precursors and the P2VP domain were prepared with different ratios of gold to P2VP block $(1: 1,1: 5,1: 10,5: 1,10: 1)$ by taking advantage of the association between the longpair nitrogen of the pyridine group of P2VP. The reduction of the $\mathrm{Au}^{3+} / \mathrm{PLA}-\mathrm{b}-\mathrm{P} 2 \mathrm{VP}$ composite was accomplished by hydrazine solution in order to get gold nanoparticle/PLA-b-P2VP composites, which was visually confirmed by a direct color change from bright yellow to purple. In this work, ultraviolet-visible (UV-vis) spectroscopy and Fourier transform infrared spectroscopy (FTIR) were used to confirm the association between gold precursors and pyridine groups as well as the synthesis of gold nanoparticles. The composite which labeled as $\mathrm{R} 3\left(\mathrm{Au}^{3+}: \mathrm{P} 2 \mathrm{VP}=10: 1\right)$ showed the highest peak current based on the cyclic voltammetry (CV) measurement. Furthermore, graphene oxide $(\mathrm{GO})$ was added into $\mathrm{R} 3$ to prepare $\mathrm{BCP} / \mathrm{AuNPs} / \mathrm{GO}$ composite and reduced to $\mathrm{BCP} / \mathrm{AuNPs} / \mathrm{rGO}$ through electrochemical reduction. The resulting $\mathrm{BCP} / \mathrm{AuNPs} / \mathrm{rGO}$ showed high potential to be used in amperometric biosensor.
\end{abstract}

ABSTRAK: Nanokomposit yang terdiri daripada diblok kopolimer (BCP) dan nanopartikel emas (AuNPs) boleh digunakan sebagai matrik untuk memegun enzim atau molekul lain berdasarkan struktur asas nano komposit. Dalam kajian ini, polilaktik asidblok-poli(2-vinylpyridine) (PLA-b-P2VP)/hidrogen tetrachloroaurate (III) hidrat $\left(\mathrm{HAuCl}_{4} \cdot 3 \mathrm{H}_{2} \mathrm{O}\right)$ komposit telah dihibrid dan kemudian direduksi dalam larutan diklorometana (DCM). Proses hibridasi antara prekursor emas dan domain P2VP dilakukan dengan nisbah yang berbeza; emas kepada blok P2VP (1:1, 1:5, 1:10, 5:1, 10:1) dengan mengambil peluang daripada gabungan antara kumpulan nitrogen dan kumpulan P2VP piridina. Reduksi komposit $\mathrm{Au}^{3+} /$ PLA-b-P2VP dapat dihasilkan dengan larutan hidrazin bagi mendapatkan komposit nanopartikel emas/PLA-b-P2VP, ini disahkan dengan perubahan warna daripada kuning kepada ungu. Dalam kajian ini, kehadiran-ultraungu spektroskopi (UV-vis) dan perubahan Fourier inframerah (FTIR) telah digunakan untuk mengesahkan hubungan antara prekursor emas dan kumpulan piridina serta sintesis emas nanopartikel. Komposit yang dilabelkan sebagai R3 $\left(\mathrm{Au}^{3+}\right.$ : $\mathrm{P} 2 \mathrm{VP}=10: 1)$ menunjukkan puncak tertinggi arus berdasarkan nilai kitaran voltammetri 
(CV). Tambahan, graphene oksida (GO) telah ditambah ke dalam R3 untuk menyediakan komposit $\mathrm{BCP} / \mathrm{AuNPs} / \mathrm{GO}$ dan menukarkan kepada $\mathrm{BCP} / \mathrm{AuNPs} / \mathrm{rGO}$ melalui teknik penurunan elektrokimia. Keputusan komposit $\mathrm{BCP} / \mathrm{AuNPs} / \mathrm{rGO}$ menunjukkan potensi yang tinggi untuk digunakan dalam biosensor amperometrik.

KEYWORDS: block copolymer; gold nanoparticles; poly(2-vinylpyridine); polylactic acid; cyclic voltammetry

\section{INTRODUCTION}

A glucose biosensor, consisting of a recognition element and a transducer, is the basic technology to monitor glucose levels, particularly those of diabetic patients [1]. It is widely acknowledged that nanomaterial-modified electrodes of an enzymatic biosensor play an important part in improving the sensitivity and stability of analyte detection. Among candidate nanomaterials, gold nanoparticles (AuNPs) have gained considerable attention based on their excellent conductivity and catalytic properties. AuNPs have many advantages to electrochemical sensors, including their ability to provide biocompatibility and efficient loading sites for immobilizing enzymes and further improving electron transfer between the active site and electrode [2]. Certain properties of polymers, including stability, ease of synthesis, excellent tailorability, and good processability, also attracted many researchers' attention [3]. Block copolymers (BCPs) made of blocks of different polymerized monomers linked by covalent bonds at their ends likewise attracted interest based on their structure, size, and chemical composition. Self-assembly of BCPs can generate nanostructured particles with tunable internal structures, shapes, and surface properties, which provide potential application in particle-based technology [4]. Furthermore, it is well acknowledged that incorporating nanoparticles into a polymer matrix can have a significant influence in the properties of the binding matrix, including mechanical strength, conductivity, permeability and catalytic activities [5]. Graphene attracted a lot of attention due to its' one-atom-thick planar sheet of $\mathrm{sp}^{2}$ bonded carbon atoms that are densely arranged into a 2D honeycomb-structure with superior electrical conductivity, excellent chemical stability and high surface to volume ratio [6]. Different reduction strategies were used to reduce GO into RGO, such as thermal annealing, chemical reagent reduction and electrochemical reduction [7]. Electrochemical reduction is a method that shows promise for the reduction of GO which depends on the electrochemical removal of oxygen functional groups.

In this research, polylactic acid-block-poly(2-vinylpyridine) (PLA-b-P2VP) was used for hybridization with $\mathrm{Au}^{3+}$ by taking advantages of the association between the long-pair nitrogen of the pyridine and various metal irons [8]. The synthesis of gold nanoparticles was accomplished through reduction of $\mathrm{BCP} / \mathrm{Au}^{3+}$ by using hydrazine hydrates as reducing reagent. The optimum ratio of PLA-b-P2VP/AuNPs composites was chosen based on CV results. Graphene oxide (GO) was added in to the optimum ratio composite to prepare $\mathrm{BCP} / \mathrm{AuNPs} / \mathrm{GO}$ composite and reduced to $\mathrm{BCP} / \mathrm{AuNPs} / \mathrm{rGO}$ through electrochemical reduction. The electrochemical properties of $\mathrm{BCP} / \mathrm{AuNPs} / \mathrm{rGO}$ was characterized through $\mathrm{CV}$ measurements.

\section{EXPERIMENTAL}

\subsection{Reagents and Apparatus}

Polylactic acid-block-poly(2-vinylpyridine) (PLA-b-P2VP) with molecular weight $\left(\mathrm{M}_{\mathrm{w}}\right) 38400 \mathrm{~g} \mathrm{~mol}^{-1}$ and $f_{\mathrm{PLA}}=0.36$ was used in this work. Gold(III) chloride trihydrate 
$\left(\geq 99.9 \%\right.$ trace metals basis, $\mathrm{HAuCl}_{4} \cdot 3 \mathrm{H}_{2} \mathrm{O}$ ), hydrazine solution ( $35 \mathrm{wt} \%$ in $\mathrm{H}_{2} \mathrm{O}$, $\left.\mathrm{N}_{2} \mathrm{H}_{4} \cdot \mathrm{H}_{2} \mathrm{O}\right)$ and dichloromethane $\left(\mathrm{CH}_{2} \mathrm{Cl}_{2}\right.$, anhydrous, $\left.\geq 99.8 \%\right)$ were all purchased from Sigma-Aldrich. Potassium ferricyanide $\left(\mathrm{K}_{3} \mathrm{Fe}(\mathrm{CN})_{6}\right)$ was purchased from R\&M Chemicals, Selangor, Malaysia. Graphene oxide (GO) sheets were purchased from Abalonyx, Oslo, Norway. Ultra-highly concentrated single-layer graphene oxide (UHC $\mathrm{GO}), 6.2 \mathrm{mg} / \mathrm{ml}$, was purchased from Graphene-Supermarket.com (USA).

All electrochemical experiments to characterize $\mathrm{BCP} / \mathrm{AuNP}$ composites were performed using a conventional three-electrode cell and a pocketSTAT (IVIUM Technologies, Eindhoven, Netherlands) as potentiostat/galvanostat/impedance analyzer at $25{ }^{\circ} \mathrm{C}$. A modified glassy carbon electrode (GCE, inner diameter of $3.0 \mathrm{~mm}$ ) was used as the working electrode (WE), platinum (Pt) was used as the counter electrode (CE), and silver/silver chloride $(\mathrm{Ag} / \mathrm{AgCl})$ in $3.0 \mathrm{M}$ saturated sodium chloride $(\mathrm{NaCl})$ was used as the reference electrode (RE). All electrodes were purchased from ALS Co., Ltd., Tokyo, Japan. Prior to surface modifications, the GCE was polished with diamond $(0.1 \mu \mathrm{m})$ and alumina slurry $(0.05 \mu \mathrm{m})$ purchased from ALS Co., Ltd., Tokyo, Japan, ultrasonicated in ethanol for 1 minute and then deionized (DI) water for $1 \mathrm{~min}$, and dried in a desiccator for $30 \mathrm{~min}$ before use. UV-vis spectroscopy measurements $(350-650 \mathrm{~nm})$ were performed using UviLine 9400 (SECOMAN, France) at room temperature with a $10 \mathrm{~mm}$ optical length quartz cuvette. The Fourier transform infrared spectroscopy (FTIR) investigations were carried out with the Nicolet iS50 FT-IR spectrometer (Thermo Scientific, USA).

\subsection{Hybridization of BCP and Gold Precursors $\left(\mathrm{Au}^{3+}\right)$}

Five $w t \%$ of diblock copolymer (PLA-b-P2VP) solution was prepared in dichloromethane (DCM) solution and stirred for 14 hours, followed by the hybridization between gold precursors and the P2VP block using different ratios of gold to P2VP block (labeled from $\mathrm{H} 1$ to $\mathrm{H} 5$ respectively representing $\mathrm{Au}^{3+}$ : P2VP ratios from 1:1, 1:5, 1:10, 5:1, and 10:1 hybridization samples). The hybridization samples (H1, H2, H3, H4, H5) and control (BCP in DCM) were characterized via FTIR for investigation of association between the long-pair nitrogen of the P2VP pyridine group and $\mathrm{Au}^{3+}$.

\subsection{Synthesis of Gold Nanoparticles}

The synthesis of AuNPs was accomplished through reduction by hydrazine hydrate solution which labelled to ratios of Au:P2VP as R1 (1:1), R2 (5:1), R3 (10:1), R4 (1:5), R5 (1:10), corresponding to the hybridization samples. UV-vis spectroscopy was applied to characterize the synthesis of AuNPs in PLA-b-P2VP/AuNP composites.

\subsection{Electrochemical Characterization of PLA-b-P2VP/AuNPs Composites}

Cyclic voltammetry $(\mathrm{CV})$ was performed to evaluate the electron-transfer capabilities of the modified layer based on the oxidation peak current. $0.05 \mathrm{M}$ potassium ferricyanide $\left(\mathrm{K}_{3} \mathrm{Fe}(\mathrm{CN})_{6}\right)$ solution was used as redox solution and $50 \mathrm{mV} / \mathrm{s}$ as the scan rate.

\subsection{The Preparation and Electrochemical Reduction of PLA-b-P2VP/AuNPs/GO Composite}

Graphene oxide $(\mathrm{GO})$ was added into the optimum ratio composite with the ratio of $1: 1$ in order to prepare $\mathrm{BCP} / \mathrm{AuNPs} / \mathrm{GO}$ composite and reduced to $\mathrm{BCP} / \mathrm{AuNPs} / \mathrm{rGO}$ through $30 \mathrm{CV}$ cycles of electrochemical reduction in $0.01 \mathrm{M} \mathrm{PBS}(\mathrm{pH} 5)$.

\subsection{Electrochemical Characterization of PLA-b-P2VP/AuNPs/rGO Composites}

Cyclic voltammetry $(\mathrm{CV})$ was performed to evaluate the electron-transfer capabilities of the modified layer based on the oxidation peak current of $\mathrm{BCP} / \mathrm{AuNPs} / \mathrm{rGO}$ composite 
in $0.05 \mathrm{M}$ potassium ferricyanide $\left(\mathrm{K}_{3} \mathrm{Fe}(\mathrm{CN})_{6}\right)$ solution was used as redox solution and 50 $\mathrm{mV} / \mathrm{s}$ as the scan rate.

\section{RESULTS AND DISCUSSION}

Figure 1 showed the FTIR spectrum of the hybridization samples (H1, H2, H3, H4, H5) and control sample (BCP only). The two peaks around 1434 and $1474 \mathrm{~cm}^{-1}$ are the $\mathrm{C}=\mathrm{C}$ stretching in the rings of the pyridine groups of the P2VP block. The peak around $1755 \mathrm{~cm}^{-1}$ was the $\mathrm{C}=\mathrm{O}$ stretching of the PLA block [9]. Another peak from 1580 to 1600 $\mathrm{cm}^{-1}$ was related to $\mathrm{C}=\mathrm{N}$ stretching of the pyridine group. Based on the reference, a blue shift of the $\mathrm{C}=\mathrm{N}$ stretching was related to the association of the gold ions with the longpair nitrogen in the P2VP block [8].

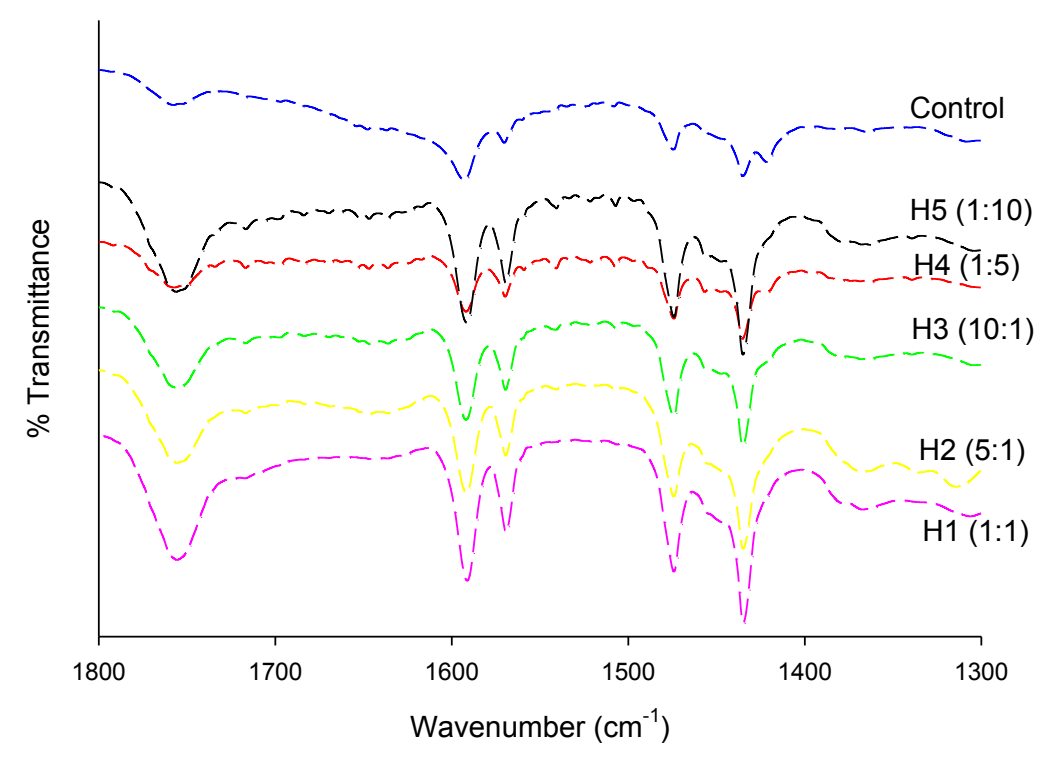

Fig. 1: FTIR spectrum of control and hybridized samples.

In addition, a blue shift was suggested as a characteristic normally attributed to the association of the gold precursors with the long-pair nitrogen in a P2VP block as the association caused an increase of binding energy associated with in-plane $\mathrm{C}=\mathrm{N}$ stretching. Table 1 also showed a small blue shift in $\mathrm{C}=\mathrm{N}$ stretching between the peak of the control sample and those of the hybridization samples; the wavenumber of $\mathrm{C}=\mathrm{N}$ stretching in $\mathrm{H} 1$ was shifted $1.93 \mathrm{~cm}^{-1}$ compared to the control. The degree of the blue shift can be applied to determine the association degree between the metal precursors and the pyridine groups of a P2VP block [8].

Table 1: Wavenumber of the $\mathrm{C}=\mathrm{N}$ stretching of pyridine groups in aP2VP block

\begin{tabular}{cc}
\hline Samples & Wavenumber $\left(\mathbf{c m}^{\mathbf{- 1}}\right)$ \\
\hline Control & 1592.94 \\
H1 & 1591.01 \\
H2 & 1591.97 \\
H3 & 1591.97 \\
H4 & 1591.97 \\
H5 & 1591.29 \\
\hline
\end{tabular}


The successful synthesis of gold nanoparticles through hydrazine reduction of $\mathrm{HAuCl}_{4} \cdot 3 \mathrm{H}_{2} \mathrm{O}$ was proved via UV-vis spectra over the wavelength range of 350 to 650 $\mathrm{nm}$. The characteristic plasmon resonance absorption band for AuNPs occurred between 500 and $600 \mathrm{~nm}$ in the visible region of the electromagnetic spectrum, which confirmed the formation of nanoparticles in the composites [10]. Figure 2 showed that all the reduction samples of the $\mathrm{BCP} / \mathrm{AuNPs}$ (R1, R2, R3, R4, and R5) exhibited the characteristic peak of gold nanoparticles. The absorbance showed the concentration gradient of gold nanoparticles as R3 $>\mathrm{R} 2>\mathrm{R} 1>\mathrm{R} 4>\mathrm{R} 5$, Furthermore, Table 2 showed the peak of gold nanoparticle absorbance in different composites. As particle size increases, the wavelength of surface plasmon resonance (SPR) related to absorption shifted to longer wavelengths; based on this, the size of gold nanoparticles in different samples can be identified. R1 $>$ R3 $>$ R2 $>$ R4=R5 [10].

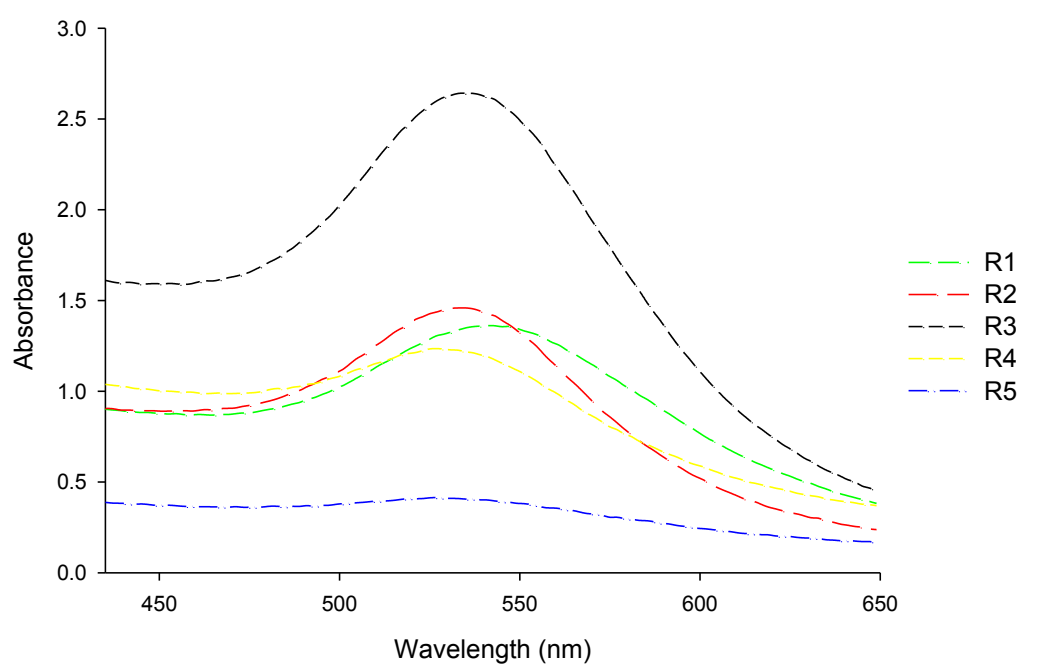

Fig. 2: UV-vis absorbance of gold nanoparticles in reduction samples (R1, R2, R3, R4, R5).

Table 2: Surface plasmon resonance (SPR) peak of gold nanoparticles via UV-vis spectroscopy

\begin{tabular}{cc}
\hline Samples & Wavenumber $\left(\mathbf{c m}^{-\mathbf{1}}\right)$ \\
\hline R1 & 543 \\
R2 & 534 \\
R3 & 536 \\
R4 & 527 \\
R5 & 527 \\
\hline
\end{tabular}

The electrochemical properties of the BCP/AuNPs composites were identified through cyclic voltammetry. Figure 3 showed that peak currents for bare GCE and GCE modified with control (only BCP) and different ratios of $\mathrm{BCP} / \mathrm{AuNPs}$ nanocomposites. The peak current of different nanomaterials modified GCE are lower than that for a bare GCE $(270.27 \pm 6.60 \mu \mathrm{A})$ owing to the non-conductive property of the BCP. 


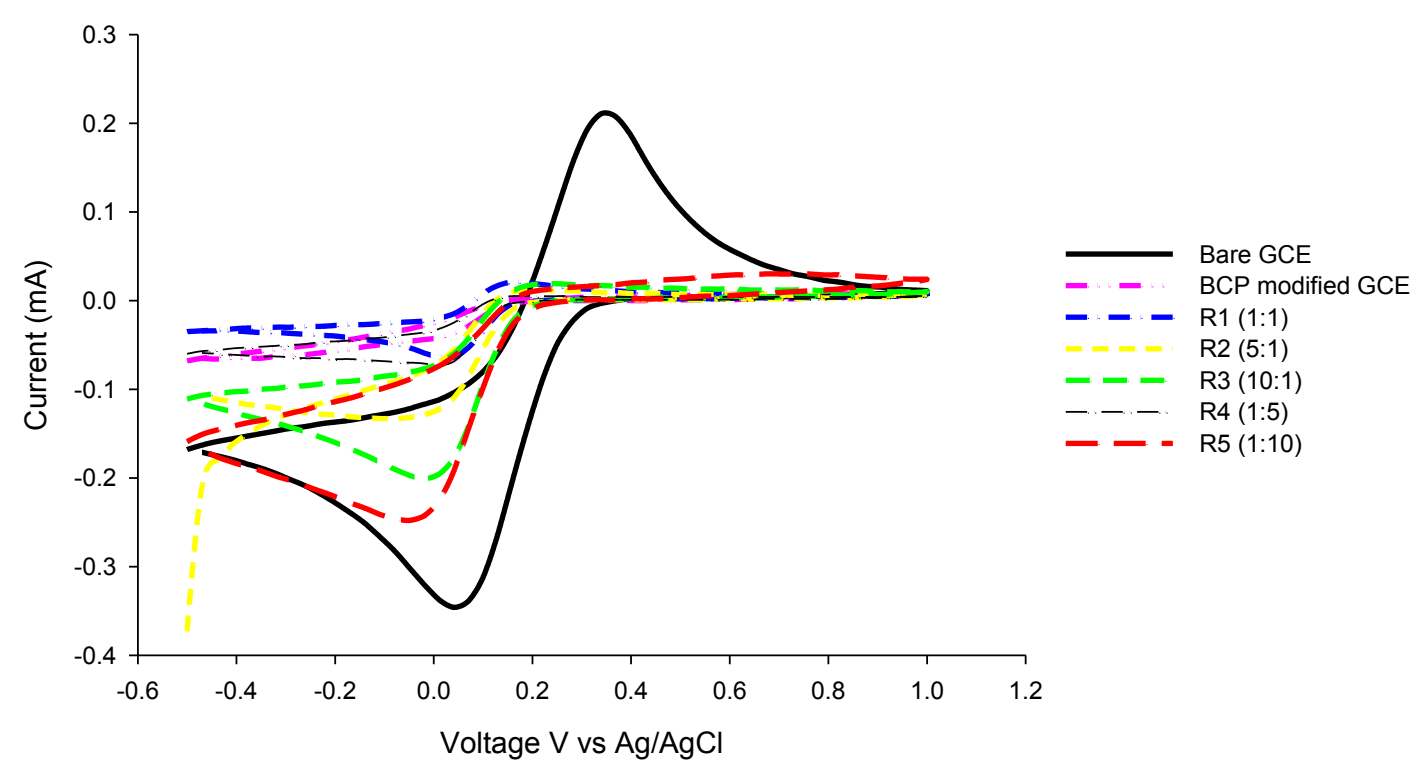

Fig. 3: CVs of bare GCE, control (only BCP), and GCEs modified with different ratios of $\mathrm{BCP} / \mathrm{AuNPs}$ nanocomposites (R1, R2, R3, R4, R5) in $0.05 \mathrm{M} \mathrm{K}_{3} \mathrm{Fe}(\mathrm{CN})_{6}$ solution at a scan rate of $50 \mathrm{mV} / \mathrm{s}$.

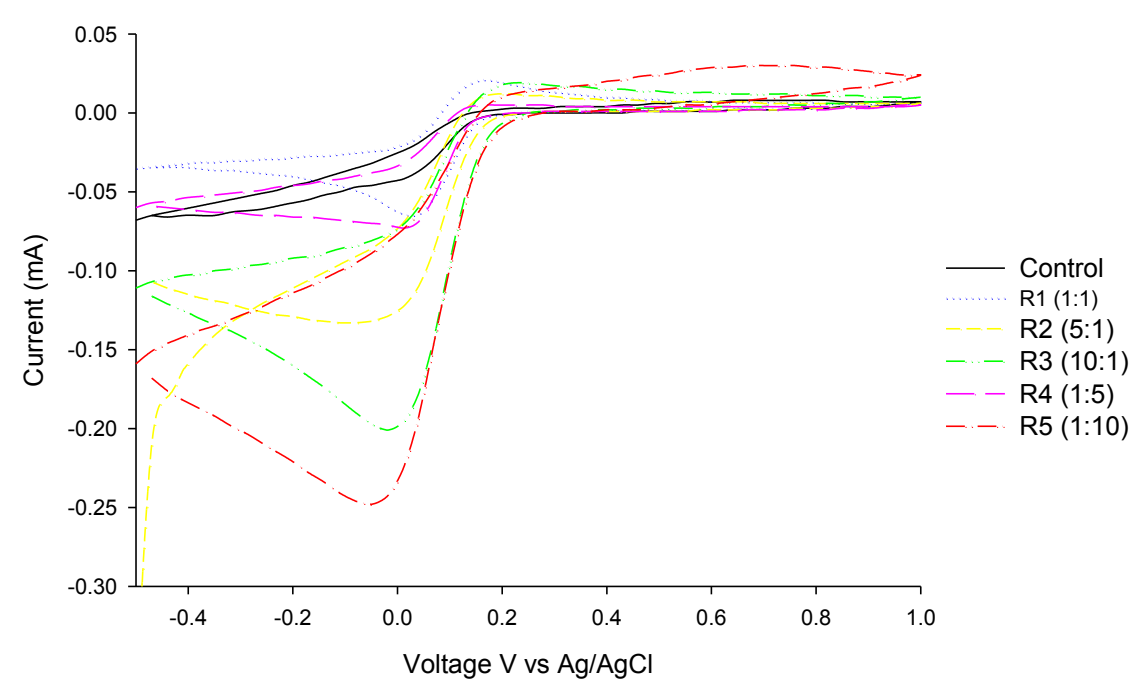

Fig. 4: CVs of BCP-modified GCEs including control and different ratios of $\mathrm{BCP} / \mathrm{AuNPs}$ nanocomposites modified $\mathrm{GCE}$ ) in $0.05 \mathrm{M} \mathrm{K}_{3} \mathrm{Fe}(\mathrm{CN})_{6}$ solution at a scan rate of $50 \mathrm{mV} / \mathrm{s}$.

However, Fig. 4 showed the peak current among BCP-modified GCEs (control: 0 $\mu \mathrm{A}), \mathrm{R} 1(34.58 \pm 0.078 \mu \mathrm{A}), \mathrm{R} 2(59.23 \pm 0.518 \mu \mathrm{A}), \mathrm{R} 3(86.62 \pm 8.30 \mu \mathrm{A}), \mathrm{R} 4(34.14 \pm$ $0.023 \mu \mathrm{A}), \mathrm{R} 5(30.27 \pm 0.980 \mu \mathrm{A})$, confirming that the higher peak current was attributable to the higher content of AuNPs in these composites.

The morphological study of the optimum R3 composite was through transmission electron microscopy (TEM). Figure 5 showed TEM image of R3. TEM study of gold nanoparticles in BCP confirmed that the particles are almost spherical in shape with an average size ranging from $10-50 \mathrm{~nm}$. 


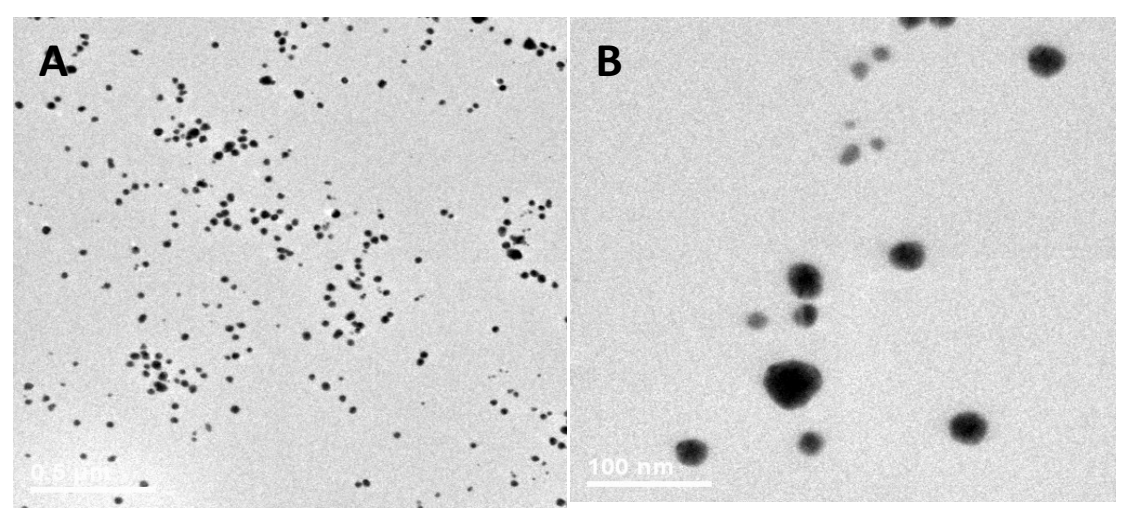

Fig. 5: TEM images of R3 $\left(\mathrm{Au}^{3+}: \mathrm{P} 2 \mathrm{VP}=10: 1\right)$, (A) low magnification of $0.5 \mu \mathrm{m}$, (B) high magnification of $100 \mathrm{~nm}$.

In order to improve the conductivity and electron transfer rate of the optimum composite (R3), graphene oxide (GO) was added into the R3 to prepare $\mathrm{BCP} / \mathrm{AuNPs} / \mathrm{GO}$ composite and reduced to $\mathrm{BCP} / \mathrm{AuNPs} / \mathrm{rGO}$ through different cycles of electrochemical reduction. The resulting $\mathrm{BCP} / \mathrm{AuNPs} / \mathrm{rGO}$ composite was electrochemically reduced by performing different continuous potential cycling $(10,20,30,40,50,60)$ in the potential range 0 to $-1.5 \mathrm{~V}$ in $\mathrm{PBS}(\mathrm{pH}$ ). After each 10 cycling reduction, the $\mathrm{P} 4 \mathrm{VP} / \mathrm{AuNPs} / \mathrm{rGO}$ composite was characterized through CV. Figure 6 showed the CV curves after every 10 cycles.

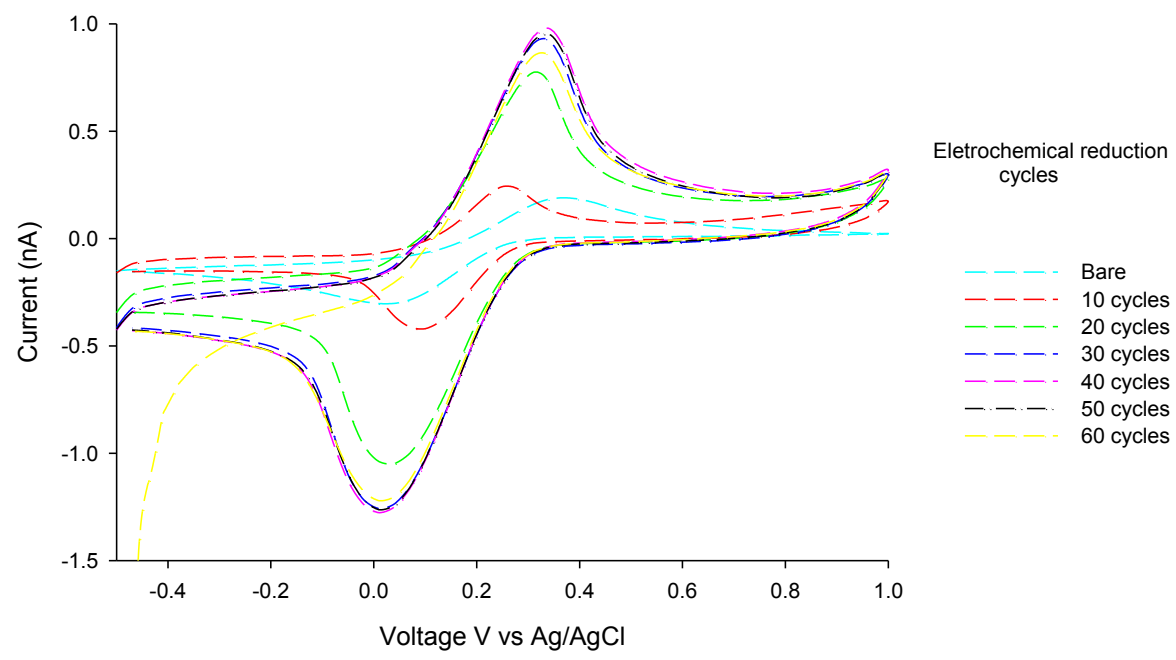

Fig. $6 \mathrm{CVs}$ of bare and $\mathrm{BCP} / \mathrm{AuNPs} / \mathrm{rGO}$ after different cycling of electrochemical reduction in $0.05 \mathrm{M} \mathrm{K}_{3} \mathrm{Fe}(\mathrm{CN})_{6}$ solution at a scan rate of $50 \mathrm{mV} / \mathrm{s}$.

As shown in Fig. 6, the peak currents of all the BCP/AuNPs/rGO modified GCE were higher than bare GCE due to the high conductivity of rGO. During different cycling of electrochemical reduction, 40 cycles showed the highest peak current (894.187 nA) compared to 10 cycles (256.054 nA), 20 cycles (704.551 nA), 30 cycles (842.356 nA), 50 cycles (892.187 nA) and 60 cycles (855.962 nA). These results also indicated that $\mathrm{BCP} / \mathrm{AuNPs} / \mathrm{rGO}$ after 40 cycling of electrochemical reduction have high potential for application in amperometric biosensors. 


\section{CONCLUSION}

In this research, we studied the preparation of different ratios for hybridization $\left(\mathrm{BCP} / \mathrm{Au}^{3+}\right)$ and reduction of $\mathrm{BCP} / \mathrm{AuNP}$ composites and $\mathrm{R} 3$ shown the potential application in glucose biosensor for enzyme immobilization through the preliminary cyclic voltammetry performance study. Additionally, graphene oxide (GO) was added in to R3 to prepare $\mathrm{BCP} / \mathrm{AuNPs} / \mathrm{GO}$ composite and reduced to $\mathrm{BCP} / \mathrm{AuNPs} / \mathrm{rGO}$ through different cycling of electrochemical reduction. The resulting $\mathrm{BCP} / \mathrm{AuNPs} / \mathrm{rGO}$ after 40 cycles of reduction show high potential to be used in amperometric biosensors based on the $\mathrm{CV}$ measurements.

\section{ACKNOWLEDGEMENT}

This work is funded by Malaysian Ministry of Higher Education (MOHE) under Fundamental Research Grant Scheme (FRGS) (Ref: FRGS14-105-0346) and Research Acculturation Grant Scheme (RAGS) (Ref: RAGS14-038-0101).

\section{REFERENCES}

[1] Sivanesan A, John SA. (2009) Gold nanoparticles modified electrodes for biosensors. In Nanostructured Materials for Electrochemical Biosensors, pp 97-128.

[2] Putzbach W, Ronkainen NJ. (2013) Immobilization techniques in the fabrication of nanomaterial-based electrochemical biosensors. Sensors, 13(4): 811-4840.

[3] Wang X, Uchiyama S. (2013) Polymers for biosensors construction. In State of the Art in Biosensors - General Aspects, pp 67-86.

[4] Smart T, Lomas H, Massignani M, Flores-Merino MV, Perez LR, Battaglia G. (2008) Block copolymer nanostructures. Nano Today, 3(3):38-46.

[5] Chiu JJ, Kim BJ, Kramer EJ, Pine DJ. (2005) Control of nanoparticle location in block copolymers. J. Am. Chem. Soc., 127(14):5036-5037.

[6] Pumera M. (2011) Graphene in biosensing. Mater. Today, 14(7): 308-315.

[7] Pei S, Cheng HM. (2012) The reduction of graphene oxide. Carbon., 50(9): 3210-3228.

[8] Lin T, Li CL, Ho RM, Ho JC. (2010) Association strength of metal ions with poly (4vinylpyridine) in inorganic/poly (4-vinylpyridine)-b-poly ( $\varepsilon$-caprolactone) hybrids. Macromolecules, 43(7):3383-3391.

[9] Yuen CWM, Ku SKA, Choi PSR, Kan CW, Tsang SY. (2005) Determining functional groups of commercially available ink-jet printing reactive dyes using infrared spectroscopy. RJTA, 9(2): 26-38.

[10] Johan MR, Chong LC, Hamizi NA. (2012) Preparation and stabilization of monodisperse colloidal gold by reduction with monosodium glutamate and poly (methyl methacrylate). Int. J. Electrochem. Sci., 7:4567-4573. 